\title{
Roots and Tubers Research and Development Activities in Countries of the Caribbean Community with a Focus on Cassava (Manihot esculenta Crantz)
}

\author{
G. C. Robin 1,*, F. Asiedu1, V. Lopez², V. Extavour ${ }^{2}$ \\ ${ }^{1}$ Caribbean Agricultural Research and Development Institute (CARDI), 2 Belmopan Close, Mona Campus, \\ University of the West Indies, Jamaica \\ ${ }^{2}$ Food and Agriculture Organization of the United Nations (FAO), Second Floor - UN House, Hastings, Christ Church, Barbados
}

Copyright $\bigcirc 2018$ by authors, all rights reserved. Authors agree that this article remains permanently open access under the terms of the Creative Commons Attribution License 4.0 International License

\begin{abstract}
The Caribbean Community (CARICOM) has prioritized roots and tuber crops as new pillars for enhancing food and nutrition security, agricultural and economic growth, reducing the high food import bill, generating employment, as well as reducing the incidence of non-communicable diseases. The cassava (Manihot esculenta Crantz) industry, though in its infancy, is recognized as having the potential for developing a wide range of value-added products, targeting existing and new markets. Over the past 15 years, the formation of a Regional Cassava Working Group, the establishment of the root crop tissue culture laboratory in St. Vincent and the Grenadines and the demonstration of new techniques in vegetative propagation and production, has led to increased productivity in CARICOM. The up-grade of farine production facilities and the selection of suitable varieties / accessions for making farine, has increased the production and consumption of the traditional cassava bread as well as the composite bread made from $40 \%$ grated cassava. The marketing of cassava value-added products, studies on cassava macro-economic impact analysis and cassava policy development are all efforts channeled towards the sustainability of the cassava industry (value chain). Studies of the effects of sweet potato (Ipomoea batatas) accessions, time of planting and zones on productivity, have led to more effective production planning and taro (Colocasia esculenta) or dasheen research has added three more genotypes to the narrow gene pool. These achievements have bolstered food and nutrition security in CARICOM.
\end{abstract}

Keywords Cassava, Sweet Potato, Taro, Value Chain, Productivity, Varieties, CARDI, FAO

\section{Introduction}

The development of the root and tuber crops value chains in the Caribbean Community (CARICOM) is emerging as a key component of a strong regional and diversified economy that can generate employment, contribute to food security, promote sustainable export trade, sustain incomes and reduce the high food import bill. The root and tuber crops research and development programmes in the Caribbean focus on increasing the production of root and tuber crops, through the introduction of new and improved varieties, development and dissemination of improved and sustainable production technologies, value addition and product development, supported by innovative market penetration strategies.

These packages of technologies are contributing to the improvement of livelihoods along the root and tuber crop value chain (Figure 1). Figure 1 is made up of an inner core (shaded green) comprising the major functional stakeholders (input suppliers, farmers, commercial vendors and agro-processors); the chain of activities is market lead. The outer core (shaded blue) are the systems of government, finance and support services that enable the stakeholders in the inner core to function effectively. The chain demonstrates how inputs (new / improved planting material), new improved and validated production technologies, have led to increased productivity, which in turn has created sustained supplies of root and tuber crops for fresh consumption, commercial exports and value-added products. 


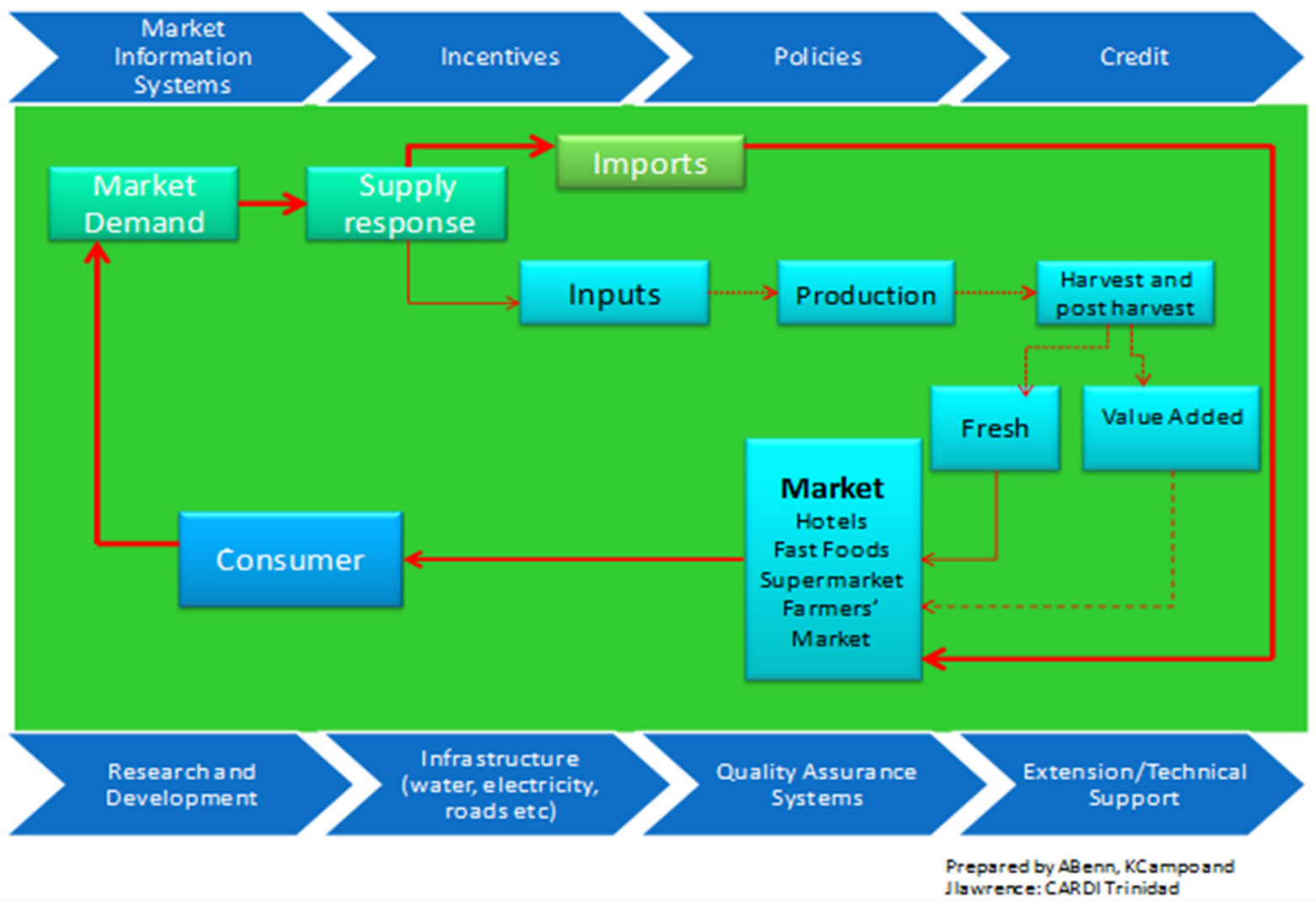

Figure 1. Generic value chain for root and tuber crops

The Caribbean Agricultural Research and Development Institute (CARDI) focus over the past five years has been in the input, production and value-added links of the value chain, and the Institute has invested in research and development innovations in the cassava (Manihot esculenta Crantz) industry (CTA [1]) that has led to:

- $\quad$ Sustained availability of clean planting material.

- Introduction of improved and higher yielding varieties.

- Introduction and dissemination of improved integrated crop management technologies.

- Selection of the appropriate varieties (suitable raw material) for processing.

- Improving the buildings and sanitation levels of small processing facilities.

The Food and Agriculture Organization of the United Nations (FAO) of the United Nations partnered with CARDI and focused on:

- Coordination.

- Processing.

- Marketing.

- Macro-economic impact analysis.

- Policy development.

Work on the above includes market information systems, policies and incentives links of the value chain (FAO [2]).

During the implementation of a Common Funds for
Commodities (CFC) project, Trinidad and Tobago Agri-Business Association (TTABA) was the agency that had commercialized and was promoting root and tuber value-added products (cassava and sweet potato composite breads, cassava wedges, sweet potatoes fries). CFC provided support to expand / enhance the activities of TTABA. The processes used in the training and promoting value-added products made from cassava and sweet potato (Ipomoea batatas) were those developed initially by TTABA (CARDI [3]).

In 2000, CARICOM gave CARDI a mandate to develop the sweet potato industry in the Caribbean, with a focus on food and nutrition security. Over the years, CARDI's focus has been on: increasing productivity through the introduction of high yielding cultivars from the International Potato Centre (CIP) (CARDI [4]); agronomy trials (Robin and Browne, [5]); integrated pest management studies (Titus and Dalip, [6]; Jackson, et al. [7]); post-harvest handling studies; biochemical analysis of the various varieties / accessions; and standardization of the various varieties / accessions in the region through morphological studies. The range of activities described and their findings are documented in the Sweet Potato Technical Manual (CARDI [4]). Sweet potato remains one of CARICOM's priority commodities selected for food and nutrition security and therefore, one of CARDI's goals is to ensure that sweet potato must always be available at affordable prices. To achieve this, technicians 
and farmers must have a clear understanding of the sweet potato production systems and the true potential of the varieties, across seasons and agro-ecological zones, using validated technologies.

Taro (Colocasia esculenta) or dasheen is another root crop that has been targeted for food and nutritional security; however, Caribbean scientists have expressed concerns over the years on the narrow genetic base that exists in the commercial taro genotypes. These concerns led to CARDI's involvement in the International Network of Edible Aroids (INEA) and the introduction and validation of new genotypes to the region. On completion, the project added three new genotypes to the commercial gene pool (Lebot, et al. [8]).

A number of recently-concluded projects funded and supported by various agencies or cooperative agreements, for example, the Common Fund for Commodities (CFC), the European Union (EU), FAO, Inter-American Institute for Cooperation on Agriculture (IICA), the South Pacific Commission (SPC) / Centre de Cooperationale en Recherche Agronomique pour le Developpement (CIRAD), and the CARICOM / Japan Friendship and Cooperation Fund, used an integrated approach to the production and marketing of cassava, for the enhancement of incomes across the value chains. For sweet potato and taro (dasheen), specific focus was on the input, and production links in the value chain. Stakeholder-identified constraints were alleviated with development and application of appropriate technologies, use of proven training techniques, strengthening of farmers organizations and support for the maintenance of quality standards.

The results of project activities were disseminated to all CARICOM countries, and the flow of information, expertise and experiences were disseminated widely within the region. This paper presents the range of activities carried out by CARDI, FAO and other partnering and collaborating institutions / organizations for the development of the root and tuber crop industry in the

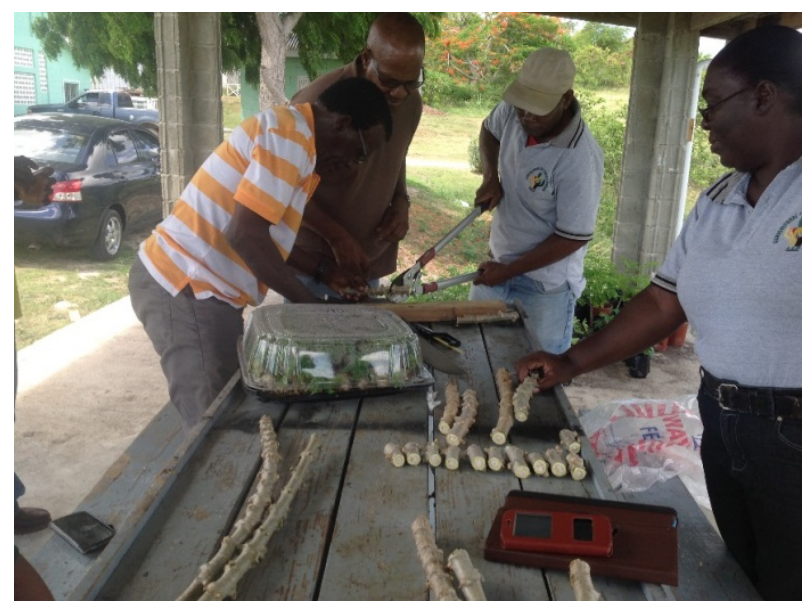

\section{CARICOM}

\section{Materials and Methods}

\subsection{Cassava}

\subsubsection{Production of clean planting material}

The project funded by the $\mathrm{CFC}$ and the EU, constructed in St. Vincent and the Grenadines, a US\$500,000 tissue culture laboratory in Orange Hill and weaning and hardening facilities in Perseverance, for root and tuber crops. Both facilities will provide services to CARICOM Member States. The project also erected weaning and hardening facilities in Antigua and Barbuda.

\subsubsection{Cassava Germplasm and Planting Material}

Cassava, sweet potato and taro germplasm banks, comprising both indigenous accessions and introduced improved varieties, are maintained in vitro (in St. Vincent and the Grenadines and Jamaica) and in vivo in most other CARICOM member countries. CARDI established systems for rapid multiplication and distribution of cassava planting material, as well as conducted training sessions in propagation of planting material in several countries (Antigua and Barbuda, Barbados, Belize, Dominica, Grenada, Guyana, Jamaica, St. Lucia, St. Kitts and Nevis, St. Vincent and the Grenadines and Trinidad and Tobago). The training sessions involved the use of mini-stem hard wood and semi-mature stem cuttings (IITA [9]). Humidity bins were built to facilitate the weaning and hardening of the mini-stem cuttings (Figure 2). Training sessions focused on propagators, extension officers, and farmers. The sessions were organized and conducted with the Ministries of Agriculture extension staff and CARDI technicians. Technicians were also trained in the weaning and hardening of cassava, sweet potato and taro (dasheen) tissue culture plantlets.

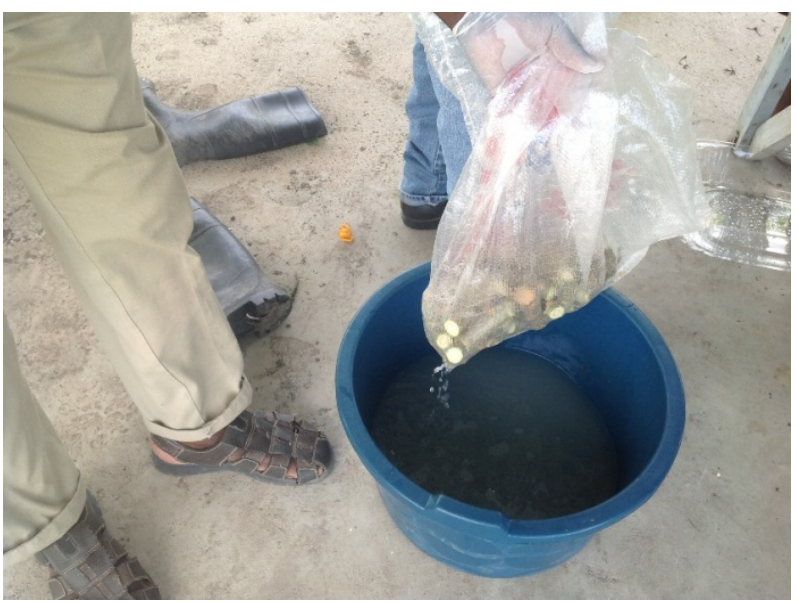



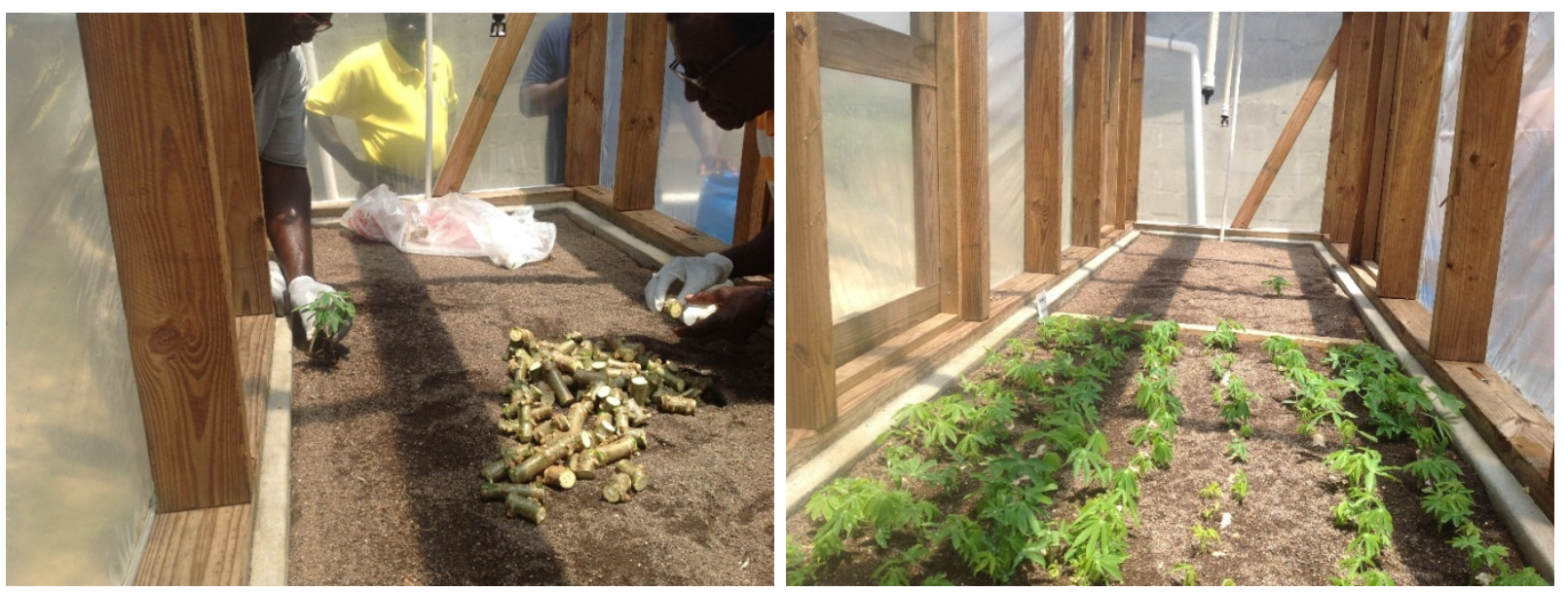

Figure 2. CARDI staff conduct training sessions, in cassava mini-stem propagation, using newly constructed humidity bins at CARDI's Research Station at Betty's Hope, Antigua and Barbuda

\subsubsection{Cassava Production and Productivity}

Cassava production and productivity constitute one of the major links of the cassava value chain and have been a prime target for intervention. Three examples are provided here.

In the first example, CARDI validated in St. Vincent and the Grenadines the production of a wide range of local accessions (Punt, Butter and White stick) and introduced (SM 1565-15/bitter; CM 7514-8/bitter; CM 4919-1/bitter; CM 7514-7/sweet; CM 3306-4/sweet; BRA 383/sweet) cassava varieties from CIAT in Columbia. An experiment comprising four randomized blocks, each consisting of four accessions and five varieties within each block, was established at the CARDI's Research Station at Rabacca in December 2009. Ridges $45 \mathrm{~cm}$ wide and $90 \mathrm{~cm}$ apart were prepared. Planting sticks, $30 \mathrm{~cm}$ long and treated with a cocktail of insecticides; dimethomorph $(15 \mathrm{~mL}$ per 4.5 litres), diazinon (60 mL per 4.5 litres) and nutrex $(15 \mathrm{~mL}$ per 4.5 litres), were planted $30 \mathrm{~cm}$ apart, at $45^{0}$ along each ridge. Plot size was $16 \mathrm{~m}^{2}$. The plots were manually weeded, and brush cut monthly until the foliage gave complete ground cover. Plots were fertilized once with NPK 16:8:24 at the rate of $25 \mathrm{~g}$ per plant, five weeks after planting. At seven months, the crop was infested with broad mite, and a spray regime of azadirachtin, chlorfenapyr and abamectin rotated at two-week intervals was applied at the recommended rates to control the pest. Each insecticide was applied at the rate of $5 \mathrm{~mL}$ per 4.5 litres, from June to October 2010. The experiment was harvested in December 2010. Data was collected on marketable, unmarketable and total yield. GENSTAT Version 19 was used to analyze the data.

In the second example, FAO completed analysis of farmer production practices highlighting the impact of improved production practices on cassava yield (CARDI [3]). An initial analysis of the import replacement was also completed as part of the assessment to develop the cassava industry.
The third example focused on the development of technology packages, the establishment of demonstration plots to train farmers (CARDI [3]), and the intra-regional transfer of clean, disease-free planting material.

The protocol for the movement of disease-free cassava planting material in CARICOM prepared by CARDI in collaboration with FAO, which is intended to facilitate the movement and availability of good quality planting material throughout the region was endorsed by the $51^{\text {st }}$ meeting of CARICOM's Council for Trade and Economic Development (COTED) in October 2015. The draft protocol is still undergoing technical and legal review.

\subsubsection{Cassava Value Adding}

Examples of actions that were undertaken regarding cassava value added were the processing of cassava into farine (dried grated cassava, after the liquid / starch has been extracted) and the manufacture of cassava composite bread. The farine processing activities took place on both private and government properties. The farine processing plants of seven small processors in St. Vincent and the Grenadines were assessed and upgraded.

A baseline survey of the seven small processors was conducted by the Food Technologist in the Ministry of Agriculture, and Food Safety Professionals from the Bureau of Standards in St. Vincent and the Grenadines. The survey reviewed the legal status of the facilities, their corporate functions, physical structures, floor plans, equipment outlays, sanitation levels and throughputs.

The Farine Processing Factory of the Ministry of Agriculture at Orange Hill, St. Vincent and the Grenadines was used to evaluate the farine making potential of the cassava varieties studied under 2.1.3 above. Tubers from each variety were processed at the processing factory and data on cassava weight to farine ratio were collected. GENSTAT - Version 19 was used to analyze the data.

FAO in partnership with the Caribbean Agri-business Association (CABA) developed technology packages to produce grated cassava and cassava flour considering the 
food safety and handling practices required for commercial production of both products. In addition, an agro-industrial equipment guide has been developed to guide commercial production of grated cassava and cassava flour (FAO [10]). Cost models to produce cassava flour and grated cassava were also completed.

CARDI and FAO (under separate projects) coordinated demonstrations of commercial production of composite bread - made with $40 \%$ grated cassava and $60 \%$ wheat flour, across countries of the region (Antigua and Barbuda, Barbados, Belize, Dominica, Grenada, Guyana, Jamaica, St. Kitts and Nevis, St. Lucia, St. Vincent and the Grenadines, Suriname). This activity was conducted in collaboration with the master baker from CABA. In addition, demonstrations were also held in utilizing cassava flour to replace up to $30 \%$ wheat flour in cassava composite bread. Furthermore, FAO engaged the University of the West Indies, at the St Augustine Campus, in Trinidad and Tobago to develop the supporting technical and processing specifications for cassava composite bread, using grated cassava and cassava flour, based on the formulations developed by CABA. The nutritional value of the final product was also assessed.

\subsubsection{Cassava Market Development and Promotion}

Market development support was provided by FAO in Barbados, Grenada, St. Vincent and the Grenadines, Jamaica and St. Lucia (FAO [11]). Market linkage workshops were hosted in each country linking farmers to processors. The objective of these farmer- workshops were the identification of the critical success factors needed to supply cassava to agro-processors.

In Barbados and Grenada, the market analysis and linkage activities were extended and FAO developed national market development strategies and action plans for each country (FAO [12], FAO [13]).

In November 2017 FAO conducted feeding trials in Barbados, where corn was replaced by cassava when feeding small ruminants and pigs (FAO [14]). Simultaneously workshops were conducted to train farmers and processors in the utilization of cassava skins, peels and leaves in animal feed formulation.

The increased utilization of cassava and cassava products in households and hospitality industry was promoted by FAO through the organization's support of three pilot demonstrations in Barbados. In addition, regional promotion, advocacy and communication tools were developed and included:

- Pilot in-store demonstrations of cassava-based recipes, including the great-cake and fish cakes in December 2014.

- Competitions in the preparation of recipes using cassava at Agro-Fest (a premier agriculture event in Barbados) in February 2015.

- The use of cassava for most of the breakfast / bakery items produced (bread, buns and great-cake) for the
CARICOM Heads of Government meeting in June / July 2015.

- Promotion of cassava and value-added products at national events such as Agro-fest 2016 and 2017 in Barbados. The promotion was done in collaboration with the Barbados Agricultural Society (BAS), Barbados Agricultural Development and Marketing Corporation (BADMC) and IICA.

- Development of a regional recipe book and recipe cards aimed at household consumption.

- Development of recipe videos for social media and television viewing of recipes submitted for various Caribbean countries.

In Antigua and Barbuda, during the Annual Mango Fest in 2015 and 2016; CARDI introduced consumers to composite bread made from grated cassava. In Jamaica the publication entitled "Celebrating the Culinary Wonders of Cassava" (McNish et al. [15]) gave added advocacy to the culinary potential of cassava. In Grenada, the Cassava Festival was hosted in 2016 and 2017 under the national Zero-hunger Initiative, promoting local dishes made from cassava, including cassava ice cream and cassava "phoulourie". In St. Lucia, World Food Day 2016 activities featured local value-added products made using cassava. To support the in-country promotion of cassava, FAO in collaboration with the Ministry of Agriculture in Grenada and St. Vincent and the Grenadines developed calendars and in St. Lucia local recipe booklets for consumers.

\subsubsection{Cassava Macro-Economic Impact Analysis}

FAO has conducted a macro-economic analysis of primary and value-added products, specifically for grated cassava and cassava flour, for the baking industry in Barbados. Similar exercises have been undertaken in other CARICOM countries. Analysis has also been completed for the production and utilization of cassava chips specifically for animal feed. These analyses took into consideration land utilization, job creation and reduction of food import bill scenarios $(10 \%, 20 \%$, up to $40 \%$ of import substitution of wheat and maize) (Ford and Dorodnykh [16]).

\subsubsection{Cassava Policy Development}

The development of a Regional Cassava Policy Framework was contracted by the CARICOM Secretariat, through the EU-funded Agriculture Policy Programme, with FAO providing technical supervision and assistance. The objective of this exercise was to provide governments with specific recommendations, along with the identification of the institutions and the relationships and arrangements between them. It was expected that this would ensure effective implementation, monitoring and evaluation of the recommendations, promote investments in the industry and therefore increase the level of: 
- Consumer demand for cassava food and non-food products.

- Productivity and products along the value chain.

- Range of new value-added products.

- Domestic, regional and international trade.

- Monitoring, evaluation and reporting developments in the industry (FAO [2]).

\subsubsection{Regional Cassava Working Group (RCWG)}

The Regional Cassava Working Group (RCWG) was established in 2015 under the auspices of the CARICOM Secretariat. Chaired by FAO, the RCWG comprises representatives from the CARICOM Secretariat, IICA, CARDI, Caribbean Development Bank (CDB), CABA, Caribbean Farmers Network (CaFAN), Organization of Eastern Caribbean States (OECS) Commission, and the Barbados Cassava Task Force. At the RCWG first meeting on 19 February 2015, the following Terms of Reference for the RCWG were formally adopted:

- Promote the concept and development of a cassava industry across the CARICOM Region.

- Promote cassava industry linkages, public and private sector and community organizations.

- Coordinate information exchange on cassava industry related projects and initiatives across the Region.

- Communicate updates and progress on the activities of members of the RCWG.

- Promote collaboration among the agencies to manage and implement the activities of the RCWG.

- $\quad$ Report to the Technical Working Group (TWG) of the CARICOM Agriculture, Food and Nutrition Cluster (AFNC) and the relevant CARICOM Organizations.

- Promote the development of cassava industry organizations at the national level.

- Promote the adoption of enabling policies at the national and regional levels.

- Facilitate the identification and the promotion of resource mobilization for the development of, and investment in, the regional cassava industry.

- Promote awareness and value of utilizing cassava-based products within the Region.
The RCWG supports and promotes the development of the regional cassava industry and interacts closely with the various institutions and agencies at the local country level. It meets at least twice a year, with FAO coordinating and reporting annually to CARICOM - Council for Trade and Economic Development (COTED) on the work of the various partner organizations, in the development of root and tuber crop sector.

A road map was developed for the cassava industry, after consultation with stakeholders and members of the RCWG (CARICOM [17]). In 2017, the RCWG, represented by FAO, made recommendations to the CARICOM Ministers of Agriculture for the establishment of multi-stakeholder, national value chain coordinating committee, to coordinate the development of national agribusiness strategy for the cassava industry (CARICOM [18]). The recommendations included a request for the private sector partners to be members of the national value chain coordinating committees.

\subsection{Sweet Potato}

In Antigua and Barbuda, activities focusing on the production link of the sweet potato value chain involved conducting of experiments, evaluating the effects of four quarterly plantings: July, October, January, and April, on ten sweet potato accessions established in three different agro-ecological zones, over a three-year period. The characteristics of the three different locations within the zones are shown in Table 1.

The ten sweet potato accessions used in the trials were Blackrock, Hurricane, Catch Me, Fine Num, Tremont, Mandela, White Drill, King Crown, 1987 and CRO2. The experiment was a randomized complete block replicated four times, with the ten sweet potato accessions (ten plots) randomized within each block. Each plot was made up of four ridges, $4 \mathrm{~m}$ long and $1.2 \mathrm{~m}$ wide. The outer ridges and the last two plants on either end of the inner ridges served as guard rows. The experiments were irrigated to eliminate the effects of moisture stress.

Table 1. Agro-climatic parameters of the three agro-ecological zones in Antigua and Barbuda

\begin{tabular}{|c|c|c|c|}
\hline \multirow{2}{*}{ Agro-ecological characters } & \multicolumn{3}{|c|}{ Location } \\
\hline & Cades Bay & Green Castle & Betty's Hope \\
\hline Elevation $(\mathrm{m})$ & 33.0 & 33.0 & 26.0 \\
\hline Annual rainfall $(\mathrm{mm})$ & $1,111.7$ & $1,081.8$ & $1,035.5$ \\
\hline Rainfall pattern & $\begin{array}{l}\text { December to May are dry } \\
\text { months. September to } \\
\text { November rainy season. }\end{array}$ & $\begin{array}{l}\text { December to May are dry } \\
\text { months. September to } \\
\text { November rainy season. }\end{array}$ & $\begin{array}{l}\text { December to May are dry } \\
\text { months. September to November } \\
\text { rainy season. }\end{array}$ \\
\hline Soil type & Blubber Valley clay & Bandals clay & Fitches clay \\
\hline Soil physical characteristics & Sandy clay loam & Clay & Sandy clay loam \\
\hline Vegetation & Forest/mangrove & Grasslands/forest & Shrub \\
\hline Temperature $\left({ }^{0} \mathrm{C}\right)$ & $\begin{array}{l}\text { Max: } 29.0 \\
\text { Min: } 24.0\end{array}$ & $\begin{array}{l}\text { Max: } 29.8 \\
\text { Min: } 24.0\end{array}$ & $\begin{array}{l}\text { Max: } 29.5 \\
\text { Min: } 25.4\end{array}$ \\
\hline
\end{tabular}


Apical cuttings $30 \mathrm{~cm}$ long were planted on ridges $30 \mathrm{~cm}$ apart. Mono Ammonium Phosphate at the rate of $25.4 \mathrm{~g}$ per plant was applied at planting, and NPK (12-12-24) $25.4 \mathrm{~g}$ per plant at five weeks after planting. Un-planted blocks were kept weed free by periodical applications of $2 \%$ glyphosate. Harvesting was conducted after six months. This timing allowed all accessions to attain full maturity (Otoo, et al. [19]). Data were collected on total and marketable yield, total number of tubers and the number of marketable tubers from plots $16 \mathrm{~m}^{2}$.

The focus was on marketable yields, as this is the main determinant of producer and exporter earnings. Marketable yields are also the focus of the supermarkets and local consumers. The parameters (tuber length $15 \mathrm{~cm}$, tuber weight $125 \mathrm{~g}$, and the incidence of pests and diseases) used for assessing marketable yields were the same as those used by the Central Marketing Cooperation of Antigua and Barbuda. GENSTAT - Version 19 was used to analyze the data.

\subsection{Taro (Dasheen)}

The input and production links in the taro value chain were addressed through the introduction and evaluation of 50 genotypes from the Pacific region. Following an initial evaluation, 25 genotypes were selected for on-farm participatory trials. There were six farmers involved in the trials and each received ten genotypes, which were planted in single rows and managed using the farmer's own practice. Plants for data collection were selected randomly. Data were collected on weight (1.0 kg and above - export market requirement), shape (oval type shape preferred), flesh colour (white to off-white), number of suckers (for the export market - suckers removed after harvest are a source of corm infection and affects corm appearance), plant height (assessment of vigour) and most importantly taste. Data were analyzed using GENSTAT - Version 19.

The 25 genotypes were simultaneously evaluated, using a randomized block experiment with three replications, at the CARDI Research Station at Rabacca, St. Vincent and the Grenadines. Annual rainfall is below $2,150 \mathrm{~mm}$, numbers of dry months are $3-6$, altitude is below 180 meters, and the soils are characterized as recent volcanic ash soils. Management of the experiment was according to the CD-ROM: Guide in producing and handling Export Quality Dasheen in the Caribbean (Robin and Pilgrim [20]). The experiment was repeated over two seasons. Parameters measured were the same as those for the on-farm participatory trials above.

\section{Results}

\subsection{Cassava}

\subsubsection{Production of clean planting material}

The new laboratory at Orange Hill, St. Vincent and the Grenadines (Figure 3) increased micro-propagation and growth chamber space by $189 \mathrm{~m}^{2}$. Similarly, the erection of the new weaning and hardening structures at Perseverance, St. Vincent and the Grenadines expanded weaning and hardening space by $334 \mathrm{~m}^{2}$.
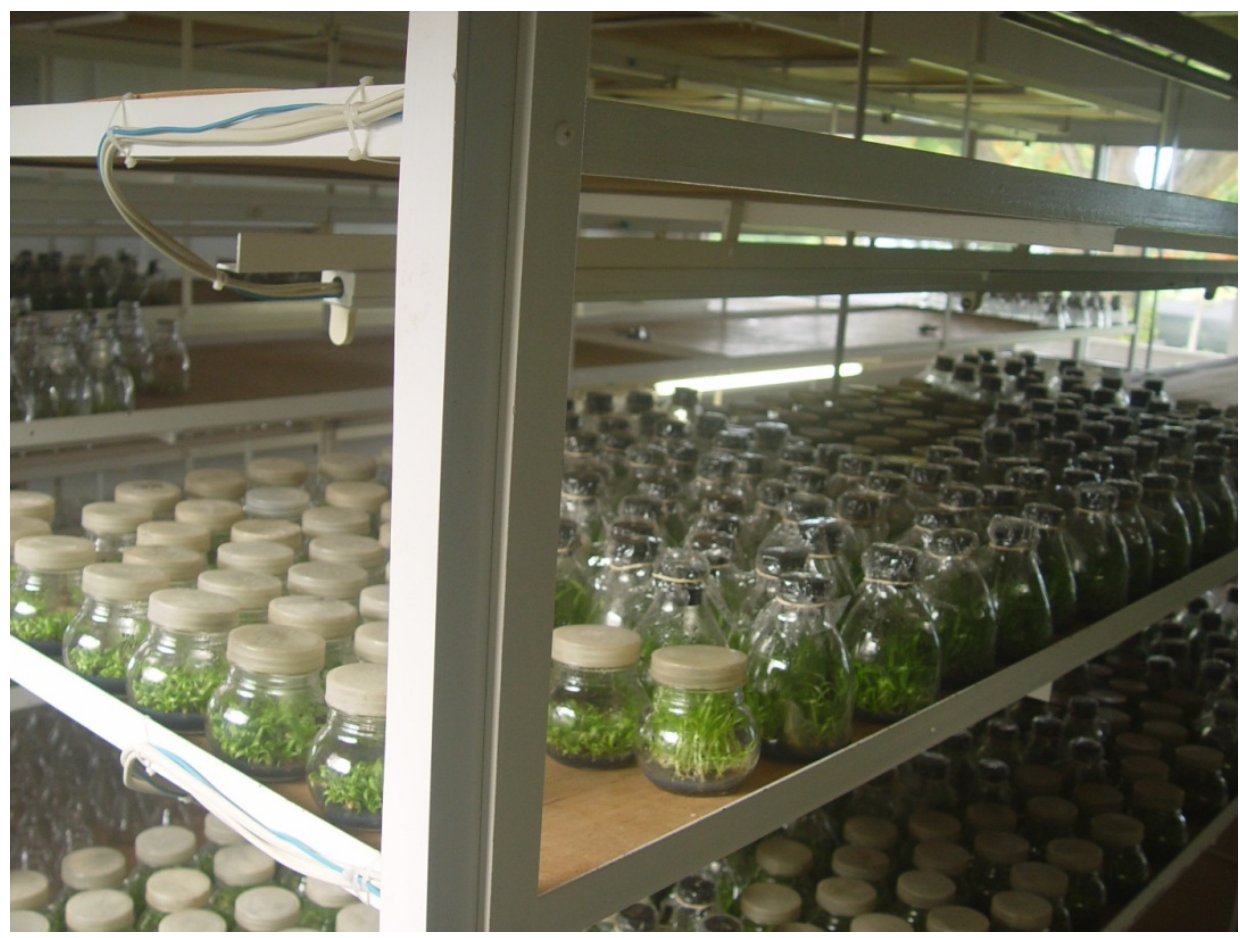

Figure 3. New tissue culture facility at Orange Hill in St. Vincent and the Grenadines 
Table 2. Yield per $\operatorname{plot}^{1}(\mathrm{~kg})$ of nine cassava varieties grown at the CARDI Research Station at Rabacca in St. Vincent and the Grenadines

\begin{tabular}{|c|c|c|c|c|c|}
\hline Varieties & $\begin{array}{l}\text { Marketable } \\
\text { yield }\end{array}$ & $\begin{array}{l}\text { Unmarketable } \\
\text { yield }\end{array}$ & $\begin{array}{l}\text { Total } \\
\text { yield }\end{array}$ & $\begin{array}{c}\text { Cassava:farine } \\
\text { ratio (based on marketable yield) }\end{array}$ & Comments \\
\hline Punt Stick & 39.2 & 9.3 & 48.5 & $8.4: 1$ & $\begin{array}{l}\text { Some tubers have double skin, } \\
\text { tubers have lots of water }\end{array}$ \\
\hline Butter Stick & 17.3 & 4.6 & 21.9 & $7.2: 1$ & $\begin{array}{l}\text { A few tubers have double skin, } \\
\text { lots of fibre, farine light }\end{array}$ \\
\hline White Stick & 38.3 & 5.4 & 43.7 & $3.9: 1$ & $\begin{array}{l}\text { Some tubers have double skin, } \\
\text { less water than the punt stick }\end{array}$ \\
\hline BRA 383 & 48.2 & 6.7 & 54.9 & $8.4: 1$ & $\begin{array}{l}\text { A few tubers have double skin, } \\
\text { less farine to the pound }\end{array}$ \\
\hline CM 3306-4 & 25.9 & 2.2 & 28.0 & $5.7: 1$ & $\begin{array}{l}\text { Easy to scrape, but the tubers are } \\
\text { tougher than the other varieties }\end{array}$ \\
\hline CM 7514-8 & 55.6 & 3.1 & 58.7 & $4.1: 1$ & Some tubers have double skin \\
\hline CM 7514-7 & 77.9 & 5.9 & 83.8 & $4.0: 1$ & Has very little starch \\
\hline CM 4919-1 & 56.5 & 15.2 & 71.7 & $4.9: 1$ & $\begin{array}{c}\text { Some tubers began to rot before } \\
\text { harvesting }\end{array}$ \\
\hline SM 1565-15 & 75.4 & 4.2 & 79.6 & $7.0: 1$ & $\begin{array}{c}\text { Has no double skin, skin thin and } \\
\text { easy to scrape }\end{array}$ \\
\hline $\mathrm{P}$ & 0.001 & $<0.001$ & 0.001 & & \\
\hline $\begin{array}{l}\mathrm{LSD}(5 \% \\
\text { level })\end{array}$ & 26.9 & 4.4 & 28.7 & & \\
\hline $\mathrm{CV}$ & 38.2 & 50.6 & 36.1 & & \\
\hline $\mathrm{df}$ & 24 & 24 & 24 & & \\
\hline
\end{tabular}

${ }^{1}$ Plot size of $16 \mathrm{~m}^{2}$

\subsubsection{Cassava Germplasm and Planting Material}

More than 600 personnel (propagators, extension officers, CARDI technicians and selected farmers) from CARICOM countries were trained in all aspects of cassava vegetative propagation and weaning and hardening of tissue culture plants. More than 1,000 sweet potato and 600 cassava tissue culture plantlets were distributed within CARICOM.

\subsubsection{Cassava Production and Productivity}

Table 2 shows that the yields of the CIAT introduced varieties were higher than the local types. The CIAT varieties CM7514-7 (77.9 $\mathrm{kg}$ per/plot $\left.16 \mathrm{~m}^{2}\right)$ and the SM1565-15 (75.4 kg/plot), were significantly higher when compared with the local accessions.

In addition, CARDI prepared several technology packages under a Letter of Agreement with FAO and these have been extensively used to conduct of training activities in several countries, including Grenada, Guyana and Jamaica. Apart from selection of planting material, rapid multiplication and understanding the growth and development of the tubers, the technology packages cover the following areas: varieties and marketing; land preparation and weed control; pest and disease management, including integrated pest management (IPM) options; and harvest and post-harvest handling of cassava.

A protocol for the movement of disease-free cassava planting material in CARICOM underwent further technical review by the competent technical body, the Caribbean Plant Health Directors (CPHD) Forum.

\subsubsection{Cassava Value Adding}

The results of the baseline survey in St. Vincent and the Grenadines indicated that of the seven processors interviewed, five had officially registered their agro-processing facilities, while two had not. Of those that had registered, one was Government owned, while three have limited liability status. Five of the facilities were shared, while two were used exclusively by their owners. Where facilities were shared, two were used by two to three persons and the other three by four to five persons. Six of the plant managers indicated that they belonged to a cluster. Five of the interviewees had open structures, while two had their structures enclosed. Two of the respondents had dirt and carpet-type floors, and five had concrete floors. The equipment used by three of the respondents can be described as manual or traditional; the other four used modern and power operated equipment. Responses varied regarding sanitation issues - three of the respondents said that they cleaned before and after every processing activity and the other four respondents did light cleaning before daily operations and a general cleaning every Friday. When not in operation, the facilities were not sanitized. All facilities have water and electricity available to them, and six had access to washrooms on their premises. The minimum quantity of fresh cassava which can be processed per day is $50 \mathrm{~kg}$, while the maximum is $1,000 \mathrm{~kg}$.

Based on the results of the survey, the St. Vincent and the Grenadines Bureau of Standards designed a generic floor plan for the small agro-processors (Figure 4). 


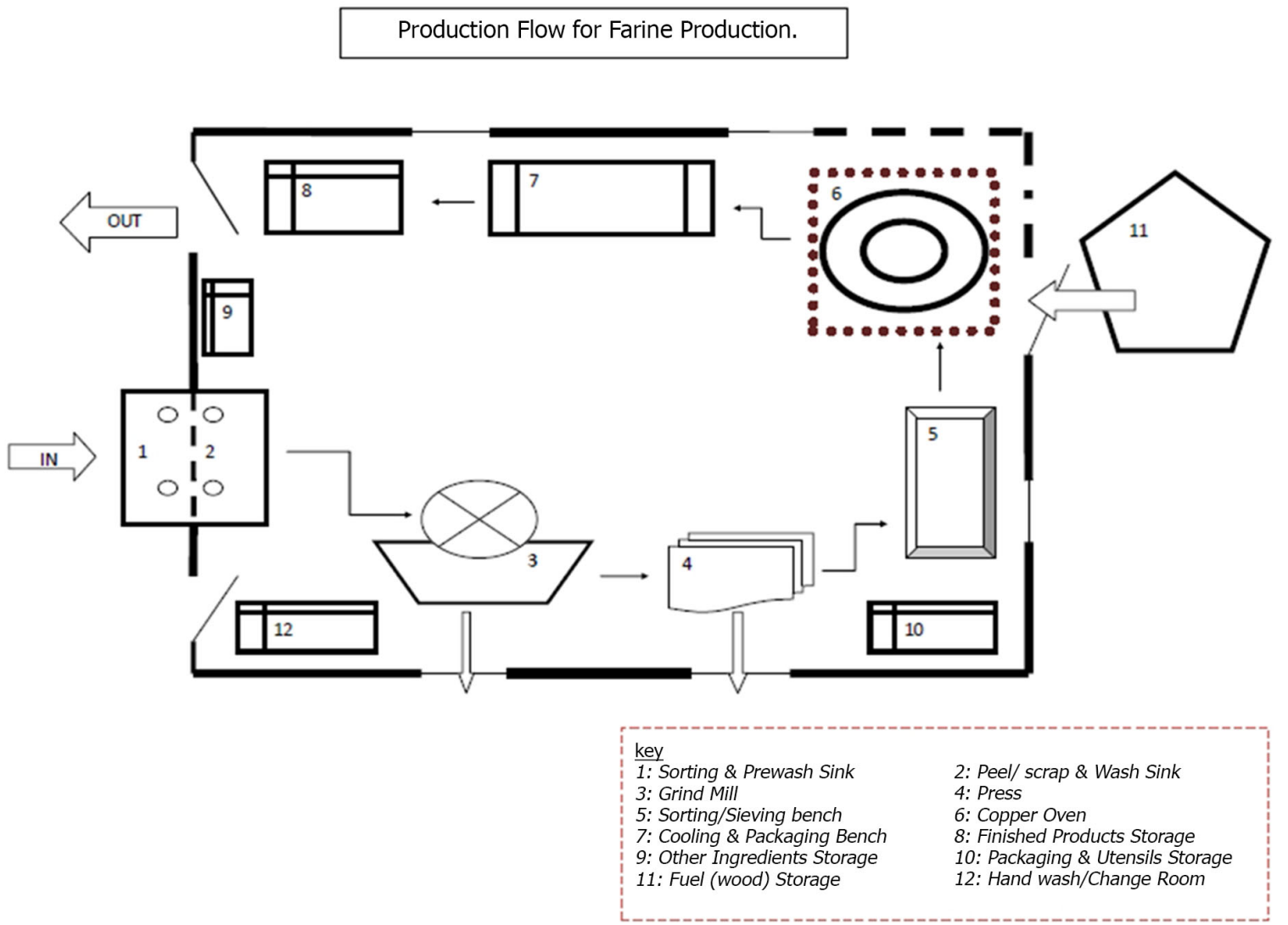

Figure 4. Approved design (floor plan) for a small farine plant

The floor plan was then designed to suit the processors existing conditions (Figure 5).

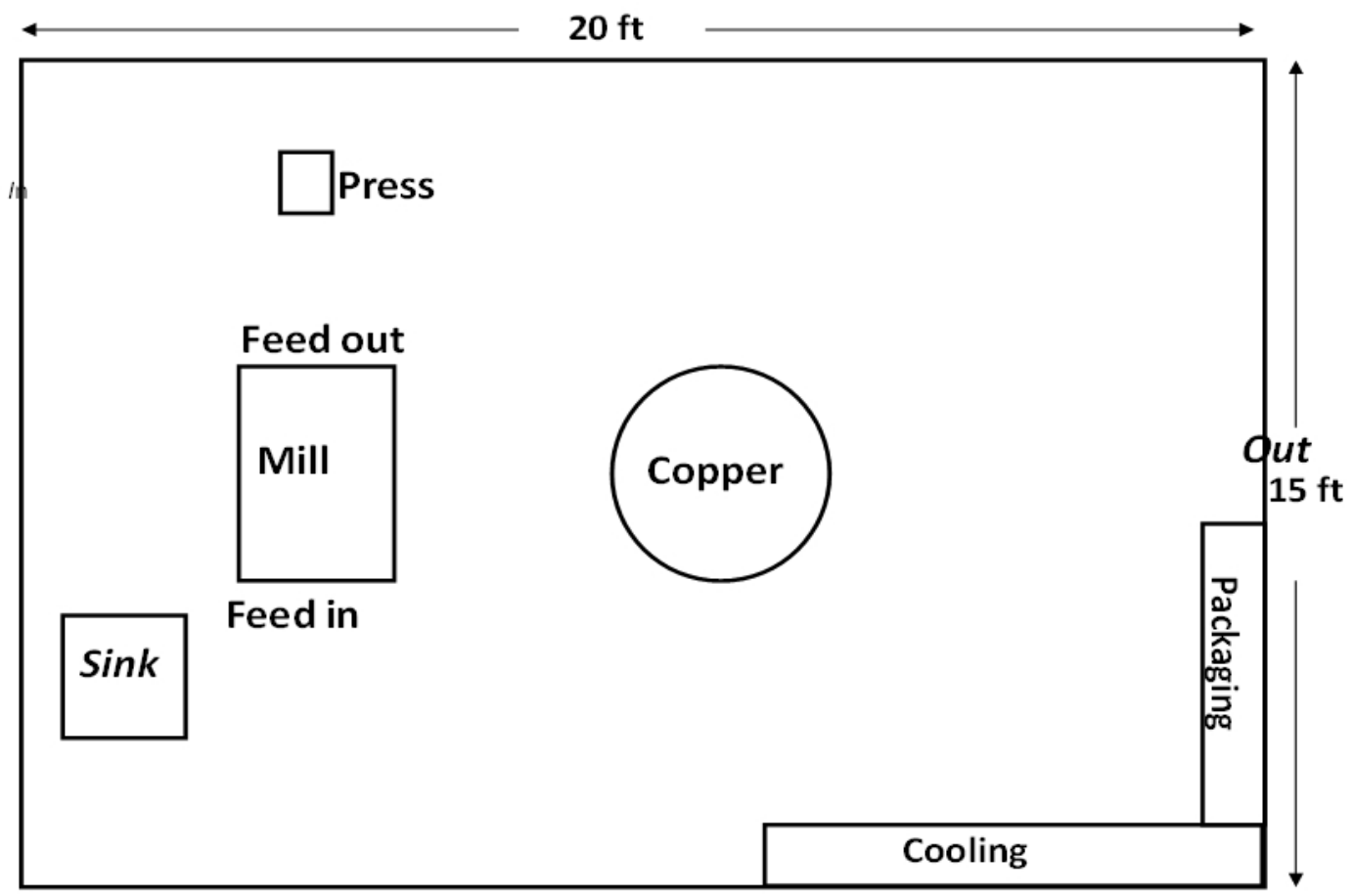

Figure 5. Layout of cassava processing plant for small processor 


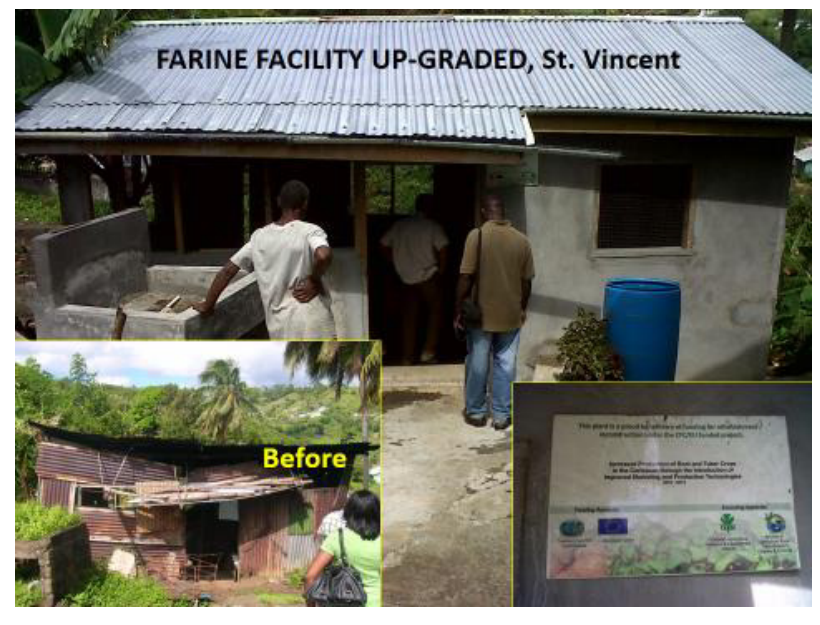

Figure 6. Refurbished farine processing facility in St. Vincent and the Grenadines

The project funded by the CFC and the EU up-graded and improved sanitation standards of five of the small Agro-processing facilities. Figure 6 shows the physical up-grade of one of the processing plants.

The results of the farine production capacity of the local accessions and the introduced cassava varieties showed that the CIAT variety, SM1565-15, had the highest cassava:farine ratio $(7: 1)$ and it was easy to peel.

The results of the analysis of the cassava composite bread, suggested that variety of cassava did not significantly affect the quality and acceptance of cassava composite bread, noting that the loaf height was higher with bread made using grated cassava compared to cassava flour. When compared to $100 \%$ wheat flour bread, cassava composite bread contained a higher carbohydrate content, a lower protein content and no significant change in micro-nutrient content (FAO [21]).

\subsubsection{Cassava Market Development and Promotion}

Cassava value-added products are normally promoted at exhibitions, and agricultural and cultural shows. FAO undertook the development of a road map for the strategic marketing of bread made with grated cassava and produced 2015 calendars for Grenada and St. Vincent and the Grenadines. Included in these calendars were three popular cassava regional recipes. The recipe book published for St. Lucia was also widely circulated. Similar marketing activities took place in St. Vincent and the Grenadines and Grenada.

Figure 7 shows a display and taste test session of cassava and sweet potato composite bread at Mango Fest 2015 in Antigua and Barbuda. The responses from the visitors to the booth, indicated that there is a demand for the composite bread and they all asked for locations where they could purchase the bread.

From the market analysis and linkage activities, policy recommendations for each country were identified and provide a template for similar studies to be conducted in other CARICOM Countries (FAO [12], FAO [13]).
Workshops to use cassava by-products in animal feed, led to the development of technology packages to be used by farmers. The initial results of the feeding trials suggested a potential reduction in the cost of animal feed for small ruminants, another priority commodity being developed by CARICOM (FAO [14]).

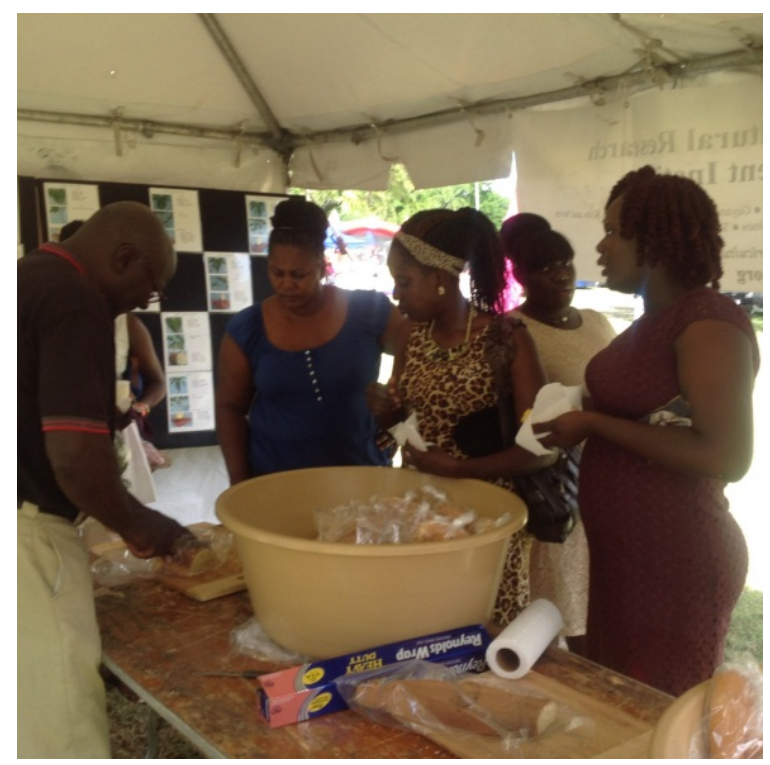

Figure 7. Visitors observing and tasting composite bread made from cassava and sweet potato in the CARDI booth at Mango Fest 2015, Antigua and Barbuda

\subsubsection{Cassava Macro-Economic Impact Analysis}

Results to date suggest that production at the farm level needs to be increased to 28 MT per ha to develop a viable and sustainable cassava industry (FAO [2]; Ford and Dorodnykh [16]). The analysis reflects the production and productivity required for commercial development of the industry. The analysis also presents the potential impact for rural spaces, where rural development is stimulated through creation of employment opportunities for small farmers, and agro-processors. The regional analysis also presents the land requirements and import replacement opportunities for cassava. The initial activities to develop the cassava industry will not result in the reduction of the food import bill in the short term; however medium to long-term development will benefit from developing the cassava industry (Ford and Dorodnykh [16]).

\subsubsection{Cassava Policy Development}

A consultant's report (Stewart [22]) indicated that the cassava industry in CARICOM was highly underdeveloped and was, in fact, at an infant stage of development. However, the assessment of the industry also pointed to numerous opportunities regarding potential utilization for a wide range of value-added products targeted at existing and new markets. The report, however, indicated that the number one problem that the region faced, was that of inadequate investment in the industry and the 
policy framework must address this.

\subsubsection{Regional Cassava Working Group (RCWG)}

There has been more efficient communication between implementing partners and collaborators, and the implementation of project activities has been timely and within the established schedules and guidelines. The Ministerial COTED endorsed the establishment of national value chain coordinating mechanisms to support development of the national and regional cassava industries. Endorsement was also given for the inclusion of the private sector in the RCWG (CARICOM [18]).

\subsection{Sweet Potato}

Table 3 shows the yields from the ten accessions in the three different locations. At Green Castle, Catch Me (20.8 $\left.\mathrm{kg} / \mathrm{plot} 16 \mathrm{~m}^{2}\right)$ and Hurricane $(13.2 \mathrm{~kg} / \mathrm{plot})$ gave the highest marketable yields $(\mathrm{P}<0.001)$. At Betty's Hope, differences in accession yields were not significant; however, the accession Hurricane gave the highest yield
(13.3 kg/plot). In Cades Bay, Catch Me (24.3 kg/plot) and Fine Num $(16.1 \mathrm{~kg} /$ plot gave the highest yields $(\mathrm{P}<0.001)$. Overall the highest yielding accessions were Catch $\mathrm{Me}$ $(16.5 \mathrm{~kg} / \mathrm{plot})$ and Hurricane $(11.5 \mathrm{~kg} / \mathrm{plot}) \mathrm{P}<0.001$.

Table 4 shows that at Green Castle, marketable yields for the January $\left(9.7 \mathrm{~kg} / \mathrm{plot}\left(16 \mathrm{~m}^{2}\right)\right)$, July $(9.6 \mathrm{~kg} / \mathrm{plot})$ and October plantings $(10.6 \mathrm{~kg} / \mathrm{plot})$, were comparable; but were significantly higher than the April plantings (3.2 $\mathrm{kg} / \mathrm{plot}) \mathrm{P}<0.001$. At Betty's Hope, the April and July plantings gave no marketable yield, however, the January and October plantings gave marketable yields of 5.7 and $9.1 \mathrm{~kg} / \mathrm{plot}$, respectively. Similar trends were observed at Cades Bay, where significantly $(\mathrm{P}<0.001)$ higher marketable yields were obtained for the January $(17.1 \mathrm{~kg} /$ plot) and October $(17.5 \mathrm{~kg} / \mathrm{plot})$ plantings when compared with the April and July plantings, which yielded $6.8 \mathrm{~kg}$ and $3.5 \mathrm{~kg}$ per plot, respectively. Overall the highest marketable yields were obtained from the January (10.9 $\mathrm{kg} / \mathrm{plot})$ and the October (12.3 kg/plot) plantings (P $<0.001)$.

Table 3. Marketable yield (kg/plot $\left.{ }^{1}\right)$ of ten sweet potato varieties/accessions grown at the Green Castle, Betty's Hope and Cades Bay Research Stations in Antigua and Barbuda

\begin{tabular}{|c|c|c|c|c|c|c|c|c|c|c|c|c|c|c|}
\hline \multirow{2}{*}{ Yield } & \multicolumn{10}{|c|}{ Accessions } & \multirow[t]{2}{*}{$\mathrm{P}$} & \multirow[t]{2}{*}{$\begin{array}{c}\text { LSD } \\
5 \% \\
\end{array}$} & \multirow[t]{2}{*}{$\mathrm{CV}$} & \multirow[t]{2}{*}{$\mathrm{df}$} \\
\hline & $\mathrm{A} 1^{*}$ & A2 & A3 & A4 & A5 & A6 & A7 & A8 & A9 & A 10 & & & & \\
\hline & \multicolumn{10}{|c|}{ Green Castle } & & & & \\
\hline \multirow[t]{2}{*}{$\begin{array}{l}\text { Weight of } \\
\text { marketable } \\
\text { tubers }(\mathrm{kg})\end{array}$} & 5.5 & 13.2 & 20.8 & 7.4 & 5.0 & 6.1 & 7.8 & 5.3 & 6.9 & 4.7 & $<0.001$ & 6.3 & 52.5 & 27 \\
\hline & \multicolumn{10}{|c|}{ Betty's Hope } & & & & \\
\hline \multirow[t]{2}{*}{$\begin{array}{l}\text { Weight of } \\
\text { marketable } \\
\text { tubers }(\mathrm{kg})\end{array}$} & 7.0 & 13.3 & 8.5 & 8.6 & 1.3 & 9.3 & 9.0 & 3.6 & 8.2 & 5.0 & 0.270 & 8.7 & $81 . .3$ & 27 \\
\hline & \multicolumn{10}{|c|}{ Cades Bay } & & & & \\
\hline \multirow[t]{2}{*}{$\begin{array}{l}\text { Weight of } \\
\text { marketable } \\
\text { tubers }(\mathrm{kg})\end{array}$} & 9.9 & 14.6 & 24.3 & 16.1 & 9.1 & 6.6 & 10.9 & 8.6 & 7.4 & 3.6 & $<0.001$ & 6.1 & 37.8 & 27 \\
\hline & \multicolumn{10}{|c|}{ Accession means } & & & & \\
\hline $\begin{array}{l}\text { Weight of } \\
\text { marketable } \\
\text { tubers }(\mathrm{kg})\end{array}$ & 6.3 & 11.5 & 16.5 & 9.3 & 4.9 & 5.8 & 7.7 & 5.2 & 6.2 & 3.6 & $<0.001$ & 2.9 & 32.4 & 54 \\
\hline
\end{tabular}

${ }^{1}$ Plot size $=16 \mathrm{~m} 2$

*A1 = Blackrock, A2 = Hurricane, A3 = Catch Me, A4 = Fine Num, A5 = Tremont, A6 = Mandela, A7 = White Drill, A8 = King Crown, A9= 1987, $\mathrm{A} 10=\mathrm{CRO} 2$ 
Table 4. Marketable yield $\left(\mathrm{kg} / \mathrm{plot}^{1}\right)$ of ten sweet potato varieties/accessions planted in the months of January, April, July and October at the Green Castle, Betty's Hope and Cades Bay Research Stations in Antigua and Barbuda

\begin{tabular}{|c|c|c|c|c|c|c|c|c|}
\hline \multirow{2}{*}{ Parameter measured } & \multicolumn{4}{|c|}{ Planting season } & \multirow{2}{*}{$\mathrm{P}$} & \multirow{2}{*}{$\begin{array}{c}\text { LSD } \\
5 \%\end{array}$} & \multirow{2}{*}{$\mathrm{CV}$} & \multirow{2}{*}{$\mathrm{df}$} \\
\hline & January & April & July & October & & & & \\
\hline & \multicolumn{4}{|c|}{ Green Castle } & & & & \\
\hline \multirow[t]{2}{*}{ Weight of marketable tubers $(\mathrm{kg})$} & 9.7 & 3.2 & 9.6 & 10.6 & 0.002 & 3.9 & 51.1 & 27 \\
\hline & \multicolumn{4}{|c|}{ Betty's Hope } & & & & \\
\hline \multirow[t]{2}{*}{ Weight of marketable tubers $(\mathrm{kg})$} & 5.7 & $0.0^{*}$ & $0.0 *$ & 9.1 & 0.082 & 3.9 & 52.1 & 9 \\
\hline & \multicolumn{4}{|c|}{ Cades Bay } & & & & \\
\hline \multirow[t]{2}{*}{ Weight of marketable tubers $(\mathrm{kg})$} & 17.1 & 6.8 & 3.5 & 17.1 & $<0.001$ & 3.9 & 38.0 & 27 \\
\hline & \multicolumn{4}{|c|}{ Planting season means } & & & & \\
\hline Weight of marketable tubers $(\mathrm{kg})$ & 10.9 & 3.3 & 4.5 & 12.3 & $<0.001$ & 1.8 & 35.6 & 54 \\
\hline
\end{tabular}

${ }^{1}$ Plot size $=16 \mathrm{~m}^{2}$

*Marketable yields not obtained

When comparisons were made between locations (Table 5), Cades Bay $\left(11.1 \mathrm{~kg} / \mathrm{plot}\left(16 \mathrm{~m}^{2}\right)\right)$, and Green Castle $(8.3$ $\mathrm{kg} /$ plot) gave overall higher marketable yields $(\mathrm{P}<0.001)$ than Betty's Hope.

Table 5. Marketable yield $\left(\mathrm{kg} / \mathrm{plot}^{1}\right)$ of ten sweet potato varieties/accessions by location, Antigua and Barbuda

\begin{tabular}{|c|c|c|c|c|c|c|c|}
\hline $\begin{array}{c}\text { Parameter } \\
\text { measured }\end{array}$ & \multicolumn{3}{|c|}{ Zone } & P & LSD 5\% & CV & df \\
\hline $\begin{array}{c}\text { Weight of } \\
\text { marketable tubers } \\
(\mathrm{kg})\end{array}$ & 3.7 & 11.1 & 8.3 & $<0.001$ & 1.6 & 38.7 & 54 \\
\hline
\end{tabular}

${ }^{1}$ Plot size $=16 \mathrm{~m}^{2}$

Table 6. Corm characteristics recorded from the dasheen genotypes yielding $1 \mathrm{~kg}$ and over from the farmer participatory trials in St. Vincent and the Grenadines

\begin{tabular}{|c|c|c|c|c|c|c|}
\hline Farm & Genotype & Weight $(\mathrm{kg})$ & Shape & Flesh colour & Number of suckers & Plant height $(\mathrm{cm})$ \\
\hline 1 & $\begin{array}{c}1 \mathrm{BL} / \mathrm{SM} / 83 \\
2 \mathrm{BL} / \mathrm{SM} / 80 \\
3 \mathrm{CE} / \mathrm{IND} / 24 \\
4 \mathrm{BL} / \mathrm{PNG} / 10\end{array}$ & $\begin{array}{l}1.8 \\
1.6 \\
1.0 \\
1.0\end{array}$ & $\begin{array}{l}\text { Dumb-bell } \\
\text { Dumb-bell } \\
\text { Dumb-bell } \\
\text { Dumb-bell } \\
\end{array}$ & $\begin{array}{l}\text { White } \\
\text { White } \\
\text { White } \\
\text { Yellow }\end{array}$ & $\begin{array}{c}12 \\
4 \\
1 \\
5 \\
\end{array}$ & $\begin{array}{l}173 \\
127 \\
102 \\
127 \\
\end{array}$ \\
\hline 2 & $\begin{array}{l}3 \mathrm{CE} / \mathrm{IND} / 24 \\
2 \mathrm{BL} / \mathrm{SM} / 80\end{array}$ & $\begin{array}{l}1.0 \\
1.2\end{array}$ & $\begin{array}{l}\text { Dumb-bell } \\
\text { Dumb-bell }\end{array}$ & $\begin{array}{l}\text { Pink } \\
\text { Pink }\end{array}$ & $\begin{array}{l}3 \\
4\end{array}$ & $\begin{array}{c}102 \\
96\end{array}$ \\
\hline 3 & $\begin{array}{c}1 \mathrm{BL} / \mathrm{SM} / 83 \\
3 \mathrm{CE} / \mathrm{IND} / 24 \\
4 \mathrm{BL} / \mathrm{PNG} / 10 \\
2 \mathrm{BL} / \mathrm{SM} / 80\end{array}$ & $\begin{array}{l}1.5 \\
1.3 \\
1.2 \\
1.0 \\
\end{array}$ & $\begin{array}{c}\text { Dumb-bell } \\
\text { Elliptical } \\
\text { Elliptical } \\
\text { Elliptical } \\
\end{array}$ & $\begin{array}{l}\text { White } \\
\text { White } \\
\text { Yellow } \\
\text { White }\end{array}$ & $\begin{array}{c}7 \\
3 \\
23 \\
3 \\
\end{array}$ & $\begin{array}{l}160 \\
127 \\
149 \\
103 \\
\end{array}$ \\
\hline 4 & $\begin{array}{c}3 \mathrm{CE} / \mathrm{IND} / 24 \\
2 \mathrm{BL} / \mathrm{SM} / 80 \\
5 \mathrm{BL} / \mathrm{SM} / 152\end{array}$ & $\begin{array}{l}2.1 \\
1.2 \\
1.0\end{array}$ & $\begin{array}{c}\text { Dumb-bell } \\
\text { Elliptical } \\
\text { Elliptical }\end{array}$ & $\begin{array}{l}\text { White } \\
\text { White } \\
\text { White }\end{array}$ & $\begin{array}{c}10 \\
11 \\
4 \\
\end{array}$ & $\begin{array}{l}167 \\
140 \\
138 \\
\end{array}$ \\
\hline 5 & $3 \mathrm{CE} / \mathrm{IND} / 24$ & 1.4 & Dumb-bell & White & 2 & 135 \\
\hline 6 & $\begin{array}{l}2 \mathrm{BL} / \mathrm{SM} / 80 \\
6 \mathrm{BL} / \mathrm{SM} / 13\end{array}$ & $\begin{array}{l}1.1 \\
1.2\end{array}$ & $\begin{array}{l}\text { Dumb-bell } \\
\text { Dumb-bell }\end{array}$ & $\begin{array}{l}\text { White } \\
\text { White }\end{array}$ & $\begin{array}{l}6 \\
7\end{array}$ & $\begin{array}{l}68 \\
76\end{array}$ \\
\hline
\end{tabular}




\subsection{Taro (Dasheen)}

The results of the on-farm participatory trials are shown in Table 6. Under farm conditions only six of the 25 genotypes produced corms that weighed $1.0 \mathrm{~kg}$ and over. On five of the six farms, both the CE/IND/24 and the $\mathrm{BL} / \mathrm{SM} / 80$ genotypes yield $1.0 \mathrm{~kg}$ and above and overall, consistently gave marketable yields. The genotypes $\mathrm{BL} / \mathrm{SM} / 83(1.8 \mathrm{~kg})$ and $\mathrm{CE} / \mathrm{IND} / 24(2.1 \mathrm{~kg})$ gave the highest yields.
The results from the on-station experiment (Table 7), showed that there were no significant differences between genotype yields, number of suckers per plant and plant height. However, five genotypes produced corms weighing $1.5 \mathrm{~kg}$ or over. These were CE/IND/ 24 (mean yield $1.8 \mathrm{~kg}$ per plant), $\mathrm{BL} / \mathrm{SM} / 80$ (mean yield $1.6 \mathrm{~kg}$ per plant), BL/SM/83 (mean yield $1.5 \mathrm{~kg}$ per plant), $\mathrm{BL} / \mathrm{PNG} / 09$ (mean yield $1.5 \mathrm{~kg}$ per plant), and $\mathrm{BL} / \mathrm{SM} / 114$ (mean yield $1.5 \mathrm{~kg}$ per plant); these genotypes gave the highest yields.

Table 7. Mean yield (per plant) and growth characteristics of 25 taro genotypes, grown at the CARDI Research Station at Rabacca, St. Vincent and the Grenadines

\begin{tabular}{|c|c|c|c|c|c|}
\hline \multirow{2}{*}{ Genotype } & \multicolumn{5}{|c|}{ Parameters measured } \\
\hline & Weight (kg) & Shape & Flesh colour & Number of suckers & Plant height $(\mathrm{cm})$ \\
\hline $\mathrm{BL} / \mathrm{HW} / 08$ & 0.9 & Elliptical & White & 12.2 & 85.2 \\
\hline $\mathrm{BL} / \mathrm{HW} / 26$ & 1.1 & Elliptical/Cylindrical & Pink & 10.3 & 70.8 \\
\hline $\mathrm{BL} / \mathrm{PNG} / 09$ & 1.5 & Elliptical & White & 6.9 & 91.5 \\
\hline $\mathrm{BL} / \mathrm{PNG} / 10$ & 1.3 & Elliptical & Yellow & 5.9 & 83.6 \\
\hline $\mathrm{BL} / \mathrm{PNG} / 11$ & 1.3 & Elliptical & White & 7.9 & $82 . .2$ \\
\hline $\mathrm{BL} / \mathrm{PNG} / 13$ & 0.8 & Elliptical & White & 9.0 & 82.0 \\
\hline $\mathrm{BL} / \mathrm{SM} / 111$ & 1.2 & Elliptical/Cylindrical & White & 5.1 & 85.7 \\
\hline BL/SM.114 & 1.5 & Elliptical & White & 2.8 & 92.9 \\
\hline $\mathrm{BL} / \mathrm{SM} / 116$ & 0.9 & Elliptical/Cylindrical & Yellow & 5.2 & 67.0 \\
\hline $\mathrm{BL} / \mathrm{SM} / 120$ & 0.9 & Elliptical/Cylindrical & White & 7.4 & 71.4 \\
\hline $\mathrm{BL} / \mathrm{SM} / 13$ & 1.0 & Elliptical/Cylindrical & White & 1.0 & 61.0 \\
\hline $\mathrm{BL} / \mathrm{SM} / 132$ & 1.3 & Elliptical & White & 5.3 & 76.9 \\
\hline $\mathrm{BL} / \mathrm{SM} / 134$ & 1.1 & Elliptical & Pink & 1.2 & 69.3 \\
\hline $\mathrm{BL} / \mathrm{SM} / 135$ & 0.9 & Conical/Elliptical & White & 3.3 & 87.3 \\
\hline $\mathrm{BL} / \mathrm{SM} / 143$ & 1.1 & Elliptical & Pink & 0 & 50.0 \\
\hline $\mathrm{BL} / \mathrm{SM} / 149$ & 1.3 & Elliptical & Yellow & 7.9 & 95.1 \\
\hline $\mathrm{BL} / \mathrm{SM} / 151$ & 1.4 & Conical/Branched/Elliptical & White & 5.7 & 87.8 \\
\hline $\mathrm{BL} / \mathrm{SM} / 152$ & 1.3 & Elliptical/Cylindrical & White & 7.8 & 80.2 \\
\hline $\mathrm{BL} / \mathrm{SM} / 80$ & 1.6 & Elliptical & White & 4.4 & 80.7 \\
\hline $\mathrm{BL} / \mathrm{SM} / 83$ & 1.5 & Elliptical & White & 5.8 & 102.6 \\
\hline $\mathrm{CE} / \mathrm{IND} / 14$ & 0.6 & Elliptical & Yellow & 12.8 & 69.3 \\
\hline $\mathrm{CE} / \mathrm{IND} / 24$ & 1.8 & Elliptical/Branched & Pinkish-white & 3.7 & 70.4 \\
\hline CE/MAL/12 & 1.1 & Elliptical & Yellow & 9.9 & 72.3 \\
\hline $\mathrm{CE} / \mathrm{MAL} / 14$ & 1.0 & Elliptical & White & 9.2 & 78.1 \\
\hline CE/MAL/09 & 0.7 & Elliptical & White & 9.2 & 59.5 \\
\hline$P$ & 0.017 & & & 0.011 & 0.197 \\
\hline LSD & 0.4 & & & 4.7 & 20.9 \\
\hline $\mathrm{CV}$ & 24.4 & & & 54.2 & 17.8 \\
\hline $\mathrm{df}$ & 62 & & & 62 & 62 \\
\hline
\end{tabular}




\section{Discussion}

\subsection{Cassava}

\subsubsection{Production of Clean Planting Material}

The construction of the root crop tissue culture facility and the training of technicians in weaning and hardening tissue culture plantlets have increased the amount plantlets available and survival rate of these plantlets when they arrive in the different CARICOM territories.

\subsubsection{Cassava Germplasm and Planting Material}

The training of the technicians facilitated the distribution of 600 cassava and over 1,000 sweet potato tissue culture plantlets throughout CARICOM. Once the protocol for the movement of disease-free cassava vegetative planting material (Frison and Feliu [23]) is adopted by CARICOM it should further increase the availability of planting material that could be planted immediately on the farm. This will alleviate the cost associated with weaning and hardening tissue culture plantlets.

\subsubsection{Cassava Production and Productivity}

Clean planting material, supported by improved production technologies, has improved production and productivity of cassava (FAO [2]); a requirement for the industry's sustainability.

\subsubsection{Cassava Value Adding}

The audit of the small cassava processing plants by the St. Vincent and the Grenadines Bureau of Standards indicated that at the time of the inspections, the processing units were not in compliance with the requirements of the national standards on the General Principles of Food Hygiene, Food Production and Preparation. The non-compliance concerns included inappropriate environmental conditions, inadequate infrastructure and equipment to ensure and maintain Good Manufacturing Practices (GMP) in the preparation of food-safe and quality products. These concerns led to the recommendations for training the small processors in GMP and HACCP.

Evaluation of the cassava varieties / accessions, showed that the highest yielding variety (CM7514-7) did not have the best cassava: farine ratio (4:1). The SM1565-15 CIAT variety was high yielding, gave a high cassava:farine ratio (7:1) and was easy to peel. This variety was selected by the Cassava Industry Association in St. Vincent and the Grenadines as the best variety for making farine.

Generally, consumers liked the composite bread and asked about its availability. However, composite cassava bread has only been commercialized in Trinidad and Tobago since 2012 and Barbados since 2015. Training of bakers in the making of composite bread, was done in 2014 and 2015 in the other countries in CARICOM. A key challenge to the mainstreaming of the composite bread is the high cost of the raw material. The availability and high cost of the raw material, also makes it difficult for the bakers to assess the economic feasibility of the product.

Key issues to be addressed as part of ongoing development of the cassava industry include food safety handling practices by small processors and optimization of processes for making grated cassava and cassava flour (FAO [21]).

\subsubsection{Cassava Market Development and Promotion}

Bammy (a traditional Jamaican cassava flatbread), fries in Trinidad and farine in some of the smaller OECS countries, are a few of the well-established cassava value-added products in CARICOM. Other cassava value-added products are not fully commercialized and production is small-scale. These small-scale cassava products, are normally promoted at exhibitions, agricultural and cultural shows and seldom get exposed through the larger supermarket chains. To ensure that these products become economically successful, they will have to be exposed to a similar marketing process described in section 2.1.4.

\subsubsection{Cassava Macro-Economic Impact Analysis}

The macro-economic impact analysis suggested that production at the farm level needs to be increased to 28 MT per ha to develop a viable and sustainable cassava industry (FAO [3]). That is achievable, providing farmers are prepared to adopt and adapt the new innovative technologies. In addition, to improved productivity, production planning and the establishment of a coordinating mechanism are necessary to maintain supplies of cassava as well as to upgrade the cassava value chain.

\subsubsection{Cassava Policy Development}

The lack of appropriate public policies has been identified as one of the major constraints hindering the production, utilization and commercialization of cassava and cassava-based products in the region. Several formal and informal forums have concluded that with appropriate policies and quality standards, cassava could be easily transformed from "a poor man's food" into a commercial commodity for sustainable food security, poverty alleviation and income generation through production, utilization, marketing and trade of cassava and cassava-based products.

Therefore, the development of a policy incentive framework is expected to provide a policy and institutional environment that is conducive to increasing cassava production and productivity, promoting investment and encouraging private sector involvement in cassava enterprises and agribusinesses. Such a policy incentive framework should contain provisions that will:

- Ensure greater efficiency in the structure and institutional management of the cassava industry through well-defined roles of regulatory and 
promotional bodies and enhancing collaboration between key players in the industry.

- Establish clear policy incentives for production, processing, utilization and marketing of cassava and cassava-based products.

- Ensure food security, improve farmer'/ processor's income, create employment and attract private sector participation in the industry.

In the context of its nature and scope, the policy should address key issues derived from the challenges faced by the cassava industry, to include elements and objectives of:

- Effective governance policies.

- Investment incentives.

- Trade / Import policy.

- Research and development policy.

- Processing.

- Effective and efficient marketing.

- Utilization/consumption.

The expected outputs of these policy elements and objectives are thus the:

- Establishment of an institutional and legal framework.

- Establishment of cassava farmer associations in different countries within the region.

- Introduction of high yielding quality planting materials that are resistant to cassava diseases and pests.

- Enhancement of institutional budgetary reform to accommodate cassava as an important food and cash crop.

- Creation of sustainable research on production, utilization, marketing and new product development.

- Establishment of an association that will promote, coordinate and regulate the cassava industry.;

- Development and harmonization of standards of cassava and cassava-based products.

- Provision of appropriate incentive to the producers and end users of cassava and cassava-based products.

\subsubsection{Regional Cassava Working Group (RCWG)}

Since the establishment of the RCWG, there has been more efficient communication between implementing partners and collaborators; and a greater commitment to implementing project activities within the established scheduled guidelines. The projects funded by the CFC, EU and FAO all had separate project management and project implementing (coordinating) committees (units) and these bodies interacted with the RCWG. These interactions ensured that specific focus and attention was given to the range of cassava activities implemented within the various projects across CARICOM. The inclusion of the private sector in the RCWG provided additional support for the development of the cassava industry. It is recognized that a market-driven approach is necessary to develop the cassava industry across the region.

\subsection{Sweet Potato}

Variable marketable yields from different varieties have also been reported in St. Vincent and the Grenadines, Northern Territories of Australia and Papua New Guinea (Gunsam and Cordice [24]; Traynor [25]; Bang [26]). Overall the highest marketable yields were obtained from the January $(10.9 \mathrm{~kg} / \mathrm{plot})$ and the October $(12.3 \mathrm{~kg} / \mathrm{plot})$ plantings $(\mathrm{P}<0.001)$. Ramirez [27] made similar observations in Cuba. Higher marketable yields obtained in October and January are attributed to the crop receiving adequate rainfall over the growth cycle, along with the higher diurnal variation in temperatures which stimulate tuberization (Sangakkara [28]). Planting in the dry season, or later in the wet season when the crop receives lower levels of rainfall with low diurnal variations in temperatures, delays tuber initiation and reduces yields (Sangakkara [28]) and may be the cause for lower yields obtained for the April and July plantings. Zones have been found to influence yield in Cuba (Ramirez [27]), Ghana (Otoo et al. [19]), Nigeria (Tewe et al. [29]) and Zambia (Mbwaga et al. [30]).

\subsection{Taro (Dasheen)}

Farmer participatory trials and the experiments conducted at Rabacca Research Station, St Vincent showed that the $\mathrm{CE} / \mathrm{IND} / 24, \mathrm{BL} / \mathrm{SM} / 80$ and the $\mathrm{BL} / \mathrm{SM} / 83$ genotypes, consistently gave corm weights that met the minimum export requirements. The $\mathrm{CE} / \mathrm{IND} / 24$, $\mathrm{BL} / \mathrm{SM} / 80$ and the $\mathrm{BL} / \mathrm{SM} / 83$, gave $3.7,4.4$ and 5.5 suckers per plant respectively, which was low and is considered a good trait for the commercial market. The genotypes also displayed good plant vigour. These three genotypes were selected for semi-commercial production.

\section{Conclusions}

The cassava value chain, though in its early stages of development, has the most potential of all the root and tuber crops for industry development along the value chain in CARICOM. The research and development activities on planting material, through to the making of composite bread attest to this. However, exponential growth in the cassava industry will only be achieved and maintained through consistent private sector investment, supported by government policies that create an enabling environment for the industry stakeholders.

Sweet potato research results in Antigua and Barbuda indicate that yield projections for sweet potato must be guided by variety/accession performance in the different agro-ecological zones and the time of planting. The inclusion of these variables will ensure accurate projections on yields while planning and negotiating contractual arrangements geared towards food security and commercial exports. 
Recent research has expanded the taro (dasheen) gene pool with the inclusion of three new genotypes from the Pacific. These augur well for the long-term sustainability of commercial taro production for food security and export.

\section{Acknowledgements}

The authors would like to thank the CARDI staff in the CARICOM countries, FAO staff from the Regional Office in Barbados, the IICA staff in the CARICOM countries, staff of CABA in Trinidad and Tobago and Ministries of Agriculture in CARICOM for their invaluable contribution to the various projects. Last and certainly not least, $\mathrm{Mr}$. Bruce Lauckner for conducting the final English edits.

\section{REFERENCES}

[1] CTA Working Paper 17/04. February 2017.

[2] FAO. (2015). Regional Conference on Cassava in the Caribbean and Latin America. Conference Report 10 - 12 February 2014. The University of the West Indies, Cave Hill Campus. Rome 2015. 99 p. ISBN 978-92-5-108750-3.

[3] CARDI. (2014) Project Title: Increased Production of Roots and Tuber Crops in the Caribbean through the Introduction of Improved Marketing and Production Technologies (CFC/FIGG/44) Final Report for the Period from February 2010 to December 2013. Common Fund for Commodities. Date 14 February 2014. Name of the Project Executing Agency (PEA): Caribbean Agricultural Research and Development Institute (CARDI) https://commonfunds.sharepoint.com/Projects/FIGG/FIGG $-44 /$ FIGG-44\%20Final\%20Report.pdf?slrid=a939659e-10 97-5000-e179-9caf515e184e.

[4] CARDI. (2010). Sweet potato technical manual. St Augustine, Trinidad and Tobago: Caribbean Agricultural Research and Development Institute. ISBN: 978-976-617-015-8.

[5] Robin, G. and Browne, B. (2011). Evaluating the effects of different agro-ecological zones, time of planting and accessions on sweet potato yields in Antigua and Barbuda. CARDI REVIEW, Issue 11. Pp. 21- 30.

[6] Titus, P. and Dalip, K. (2006). Managing the white grub Phyllophaga spp. Paper presented at the Sweet potato Open Day/Symposium, St Kitts.

[7] Jackson D. M., Lawrence J., Dalip K. M., Chung P, Clarke-Harris D., Bohac J. R., Tolin S., Edwards,C. and Seal, D. R. (2003). The sweet potato leaf beetle, Typophorus nigritus viridicyaneus (Coleoptera: Chrysomelidae), an emerging pest in Jamaica: distribution and host plant resistance. Tropical Agriculture (Trinidad) 80: 235-242] ,

[8] Lebot, V., V. Tuia, A. Ivancic, G. V. H. Jackson, F. Saborio, G. Reyes, S. Rodriguez, G. Robin, R. Traore, L. Aboagye, J. Onyeka, W. van Rensburg, V. Andrianavalona, A. Mukherjee, M. S. Prana,D. Ferraren, B. Komolong, F. Lawac, S. Winter, M. A. A. Pinheiro de Carvalho, T. Iosefa (2017). Adapting clonally propagated crops to climatic changes: a global approach for taro (Colocasia esculenta (L.)
Schott). Genetic Resources Crop Evolution, Volume 65, Issue 2, Pp. 591-606.

[9] IITA. (1996). Research Guide 51. International Institute of Tropical Agriculture, Ibadan, Nigeria.

[10] FAO (2017a), Processing and Market Development of Cassava - Technology Transfer in the utilization of grated cassava in the Bakery Industry in the Caribbean. (Publication in press).

[11] FAO (2017b) Regional Synthesis report on cassava industry development in Barbados, Grenada, Jamaica, St. Lucia and St Vincent and the Grenadines. (Publication in process).

[12] FAO (2017c) Barbados Cassava Industry Development Strategic plan. (Publication in press).

[13] FAO (2017d) Grenada Cassava Industry Development Strategic plan. (Publication in press).

[14] FAO (2017e) Building the capacity of farmers in utilizing small scale technology systems for processing animal feed using cassava and by-products. (Publication in process).

[15] McNish J., A.E. Sheerin and C.R. Campbell (2013). Celebrating the culinary wonders of cassava. ISBN 978-976-610-961-5.

[16] Ford, D., \& Dorodnykh, E., (2016). Addressing Food and Nutrition Security Threats in the Caribbean: Lessons from the Cassava Value Chain in Barbados. Farm \& Business: Journal of the Caribbean Agro-Economic Society, Vol., 8, No., 1, July 2016, pp. 2-30

[17] CARICOM (2016). Proceedings of the Sixty-Second Special Meeting of the Council for Trade and Economic Development (COTED) - Agriculture Cayman Islands, 25-28 October 2016. (Restricted circulation).

[18] CARICOM (2017). Proceedings of the Seventy-First Special Meeting of the Council for Trade and Economic Development (COTED) - Agriculture Georgetown, Guyana, 4-6 October 2017. (Restricted circulation).

[19] Otoo, J. A., A. Missah and A. G. Carson (2001). Evaluation of Sweet potato for Early Maturity Across Different Agro-Ecological Zones in Ghana. African Crop Science Journal, Vol., 9, No., 1, March 2001, Pp. 25-31.

[20] Robin G. C., R. Pilgrim (2010). the CD-ROM: Guide in producing and handling Export Quality Dasheen in the Caribbean. IICA, Trinidad and Tobago.

[21] FAO (2017f), Variety, quality and nutrient analysis of Cassava composite bread: experiences using grated cassava and cassava flour. (Publication in process).

[22] Stewart, V. (2016) Regional Policy Framework for the Cassava based Industry Development. Final Report, CARICOM Secretariat, Funded by the EU under the 10th European Development Fund (EDF). http://agriviewcaribe.net/wp-content/uploads/2017/10/Cass ava-Industry-Reg-Policy-Framework-Final-Report-VStewa rt-Nov2016.pdf.

[23] Frison, E.A. and Feliu, E. (eds.) (1991). FAO/IBPGR Technical Guidelines for the Safe Movement of Cassava Germplasm. Food and Agriculture Organization of the United Nations, Rome/International Board for Plant Genetic Resources, Rome. ISBN 92-9043-152-0.

[24] Gunsam, C and Cordice, C. (1988). Sweet potato varietal trial: experiment conducted in St. Vincent by the Research Division, Ministry of Trade, Industry and Agriculture. St. Vincent and the Grenadines, Ministry of Agriculture, 1988 
Annual Report,

[25] Traynor, M. (2005). Sweet potato production guide for the Top End. Information booklet IB1. Darwin, Australia: Northern Territory, Government.

[26] Bang, S. (2006). Research and development projects on sweet potato by National Agricultural Research Institute. A paper presented at the Sweet Potato Workshop, Madang, Papua New Guinea, 28-29 June 2006.

[27] Ramirez, G. P. (1991). Cultivation, harvesting and storage of sweet potato products. In: Machin, D. and Nyvold, S. (eds) Roots, tubers, plantains and bananas in animal feeding. Proceedings of the FAO Expert Consultation held in CIAT, Cali, Colombia, 21-25 January 1991. Pp 203 -215 .
[28] Sangakkara, U. R. (1994). Response of Sweet Potato (Ipomoea batatas L.) to Different Planting Times.Journal of Agronomy and Crop Science, Vol. 172, Issue 2, Pp. 113-118.

[29] Tewe, O. O. Ojeniyi, F. E. and Abu, O. A. (2003). Sweet potato Production, Utilization and Marketingin Nigeria. Social Sciences Department, International Potato Centre, Lima, Peru and University of Ibadan, Oyo State, Nigeria, June 2003.

[30] Mbwaga Z, Mataa M and Msabaha M. 2007. Quality and yield stability of orange sweet potato (Ipomoea batatas) varieties grown in different Agro-Ecologies. African Crop Science Proceedings Vol. 8. Pp. 339-345 